\title{
Constitution of the White Earth Nation
}

\author{
Gerald Vizenor \\ University of New Mexico
}

\begin{abstract}
The Constitution of the White Earth Nation was ratified by sworn delegates on April 4, 2009. The Constitution declares a separation from the current federal constitution that consolidated six Anishinaabe or Chippewa reservations in Minnesota. This federal constitutional association has not served the specific interests of the citizens of the White Earth Reservation. The disposition of treaty land, for instance, and the uses of natural resources cannot equitably be decided by any other government or federation of reservations. Forty citizen delegates were appointed to deliberate the appropriate formation of an independent reservation government. In the past two years after three two-day Constitutional Conventions on the White Earth Reservation, Gerald Vizenor was named the principal writer of the new constitution. The Constitution of the White Earth Nation was ratified at the fourth Constitutional Convention. The ratified Constitution will soon be presented to the citizens of the reservation as a referendum.
\end{abstract}

Keywords: White Earth, Anishinaabe, Constitution, Nation, Minnesota.

\section{PRELUDE TO A NATIVE CHARTER}

The White Earth Reservation is located in three counties, Becker, Clearwater, and Mahnomen, in northwestern Minnesota. The legal boundaries of the reservation were established by federal treaty on March 19, 1867.

The reservation was first governed by federal agents, and with the unbidden counsel of Native elders and representatives of the community. The federal agents, who were stony and unlikable, in the main, ruled the reservation as an occupied territory held in trust by the federal government. The agents of the trust were mainly capricious and corrupt in the administration of the reservation.

The hundreds of original families on the reservation had been removed according to the treaty from a wide area of woodland settlements in the northern sections of Minnesota. Alas, federal legislation partitioned the reservation into individual allotments, and subsequent state and federal legislation separated many Native families from each other and from the treaty land. Separated by federal racialist policies, and from the land by 
legislation that favored the timber speculators of white pine and other natural resources on the reservation.

The Anishinaabe elders resisted for several generations the unreasonable partitions of ethnic and racial policies. The notion of arithmetic blood quantum was concocted as a measure to determine federal services, tribal membership, and identity. Title 25 of the United States Code names and describes the laws relevant to the services provided by the government, for instance, education, health care, housing, land claims, child protection, family justice, and graves protection and repatriation. The severe quarter blood requirements for federal services have been amended, in certain circumstances, to accommodate reservation governments. Many Natives both liberal and traditional have declared that family descent, not blood quantum, determines personal associations and identity.

The Minnesota Chippewa Tribe was established by federal legislation as a government on June 18, 1934. Six reservations, White Earth, Leech Lake, Fond du Lac, Bois Forte, Mille Lac, and Grand Portage, were consolidated by a master constitution as a federation with a single government. The purpose of the federation, according to the Revised Constitution of the Minnesota Chippewa Tribe, "shall be to conserve and develop tribal resources and to promote the conservation and development of individual Indian trust property; to promote the general welfare of the members of the Tribe; to preserve and maintain justice for its members and otherwise exercise all powers granted and provided the Indians, and take advantage of the privileges afforded by the Act of June 18, 1934.”

The Revised Constitution of the Minnesota Chippewa Tribe was adopted by the Assistant Secretary of the Interior on September 12, 1963, and equivocally ratified by voters on November 23, 1963. The Minnesota Chippewa Tribe provides that membership includes those persons of "Indian blood whose names appear on the annuity roll of April 14, 1941, prepared pursuant to the Treaty with said Indians as enacted by Congress in the Act of January 14, 1889.” Anishinaabe children born between April 14, 1941, the date of the annuity roll, and July 3, 1961, the approval date of the "membership ordinance" by federal agents, "to a parent or parents, either or both of whose names appear on the basic membership role," shall be members according to 
provisions of an application. Moreover, these contingencies persist today. Children who are "at least one quarter degree Minnesota Chippewa Indian blood born after July 3, 1961, to a member, provided that an application for enrollment” was properly filed, are considered members. The United States policies and provisions based on blood quantum as racial evidence of reservation enumeration association, separates families. This practice of blood quantum, or racial arithmetic, would in time terminate the people named the Anishinaabe.

The Anishinaabe of the White Earth Reservation convey and demonstrate sanguine notions of citizens and families. "There was no single system for determining who was a part of the community and who was not,” observed Jill Doerfler in Anishinaabeg Today, the newspaper of the White Earth Reservation. "More importantly the Anishinaabeg maintained their identity as they adapted to new ways of life at White Earth. Identity was flexible and depended on the choices of individuals. Ultimately, little was agreed upon except that rigid racial designations of 'mixed-blood' and 'fullblood' pushed by the United States government investigators were unacceptable and in direct conflict with all Anishinaabeg understandings of identity.” The Anishinaabeg "continue to use their own definitions even though they demonstrate a clear awareness" of the ethnic and racial applications of these notions by the federal government.

The Constitution of the Minnesota Chippewa Tribe was created and imposed by the federal government. The Constitution, a charter federation of six reservations, established a strong executive, and with reservation advisory committees, but no separate reservation judiciary. There were no real divisions of power in the government. The Tribal Executive Committee, for instance, "shall be authorized to manage, lease, permit, or otherwise deal with tribal lands, interests in lands or other tribal assets; to engage in any business that will further the economic well being of members of the Tribe,” and borrow money from the federal government.

The White Earth Reservation is one of the largest in the federation, and there are specific treaty, charter, and constitutional issues that should be the reserved powers of the reservation, and not decided by the federation. Tribal Executive Committee decisions about individual reservation resources, for instance, and the actual division and distribution of land claims and settlements could be adverse to the citizens of the 
White Earth Reservation. For these, and many other reasons, a new constitution was proposed to separate the White Earth Reservation from the jurisdiction of the federated Minnesota Chippewa Tribe.

Erma Vizenor, Chief of the White Earth Reservation, was reelected for a second fouryear term in 2008. She has clearly articulated a determination to create a new constitution that would provide a separation of powers, the executive, legislative, and judiciary, that would fairly protect the treaty resources and land claims of the reservation. The ratification of a new constitution would mean the separation from the federation of the Minnesota Chippewa Tribe.

Chief Vizenor invited reservation communities to nominate eligible citizens to serve as official delegates to the White Earth Constitutional Convention. And, she provided for the nomination of two at-large delegates. Erma, who is related by marriage, nominated me as a delegate, and later she named me the Principal Writer of the Constitution of the White Earth Nation.

The Constitutional Convention convened for the first time on October 19, 20, 2007, at the Shooting Star Casino Hotel, White Earth Reservation, Mahnomen, Minnesota. Judge Anita Fineday presided over the oath, a solemn promise to serve as delegates. That evening and the following day the delegates convened in groups of five to consider the course and significance of discussions about the general content of the proposed Constitution of the White Earth Nation. The delegates used the words "reservation" and "nation" in the same sense at the start of the Convention. Later, a distinction was made between the treaty reservation, cultural sovereignty, and the relevant constitutional declarations of a nation.

The delegates eagerly pronounced their confidence in the inauguration the new Constitution, and, at the same time, many delegates raised serious issues about the definition of a citizen, by blood quantum or by family descent. The word "member" was renounced in favor of “citizens” of a nation. I declared, in my introduction as a delegate, that I could imagine the day when the Constitution of the White Earth Nation would be taught in public schools, and that I would carry in my pocket a reference copy of the new Constitution. I was probably more idealistic than some delegates about the creation of an actual constitutional document, but, at the same time, I had my doubts about how 
the diverse views of forty delegates, and some delegates espoused notions of racial separatism, could be reconciled by association, discussion, and inescapable compromises to create a document of individual rights, duties, and principals of governance and justice.

Robert Dahl pointed out similar circumstances in the necessary compromises made by delegates to the Convention of the United States Constitution. "The delegates had to confront still another stubborn limit: the need to engage in fundamental compromises in order to secure agreement on any constitution at all," Dahl wrote in How Democratic Is the American Constitution? "Compromises were necessary because, like the country at large, members of the convention held different views on some very basic issues.”

The second Constitutional Convention was held on January 4, 5, 2008. The Shooting Star Casino Hotel was a comfortable and convenient place to schedule the four Conventions. Delegates arrived in the early afternoon, convened for dinner, followed by general discussions, and stayed over night for a full day to exchange ideas. Surely, some of the delegates were pleased to have the evening to gamble at the casino. The third Convention was scheduled on October 24, 25, 2008. The number of delegates in attendance had slightly but steadily decreased with each Convention. I demonstrated my concern that the attendance of delegates would be eroded to a bare majority if there were more than four conventions. Erma Vizenor was persuaded by my argument and declared that ratification would be considered on April 3, 4, 2009, at the last Convention.

Erma named me the lead or Principal Writer of the proposed Constitution, and with a committee of three advisors: Jill Doerfler, Assistant Professor of Indian Studies, University of Minnesota, Duluth; JoAnne Stately, Vice President of Development for the Indian Land Tenure Foundation; and Anita Fineday, Chief Tribal Court Judge, White Earth Nation.

Erma convened one last committee discussion session on January 9, 2009, at the Brenda Café in Minneapolis to discuss the final suggestions and changes to the draft Constitution. I made the minor changes and prepared the proposed Constitution for consideration and ratification by the delegates. 
The Constitution of the White Earth Nation was ratified by the delegates on Saturday, April 4, 2009. The ratification was by secret ballot of twenty-four delegates present. Sixteen delegates voted for ratification, and eight delegates voted against ratification. The Constitution of the White Earth Nation will now be presented to eligible citizen voters in a referendum. There are more than twenty thousand citizens of the White Earth Nation.

I duly completed the changes approved by a majority vote of the delegates, including the addition of two elected members of the Legislative Council from outside the reservation community but in Minnesota. The changes in the final version of the document were only minor. The Constitution of the White Earth Nation was posted on several websites and published in the reservation newspaper, Anishinaabeg Today.

\section{PRESENTATION AT THE FINAL CONVENTION}

The Constitution of the White Earth Nation provides and ensures a continuation of the Native practices of reciprocity, cultural survivance and sovereignty, and the foundations of Native common law.

The Constitution, ratified on Saturday, April 4, 2009, confirms in conscience and custom the principles of Anishinaabe governance, common justice, and Native continental liberty. The Constitution of the White Earth Nation entitles the delegates and citizens to say with confidence, "I know my rights."

By this Constitution we become a nation that advances the formal practices of governance, cultural sovereignty, liberty, suffrage, and the rights of citizens.

By this Constitution we exercise a new political power and communal duties derived from the traditional practices of the Anishinaabe. These were the cultural practices of continental liberty, reciprocity, courage, and the survivance of our ancestors. And by the legacy of other constitutions, documents, and the perceptive ideas of liberty inspired by the Magna Carta, we become a new nation.

The Magna Carta, The Great Charter of Freedoms, was first issued almost eight hundred years ago in 1215. The Magna Carta is the foundation chronicle of liberty in England. This ancient, original document considers grievances over feudal land, capricious 
taxation and the autocratic justice of the monarchy. The Magna Carta announced, for instance, that no person would be imprisoned, or exiled, without the lawful judgment of his peers. Later, these principles of fundamental justice were provided in the Habeas Corpus Act of 1679 in England.

The Magna Carta declared that no monarch was above the law. This document became one of the most significant influences in the development of common law and subsequent constitutions around the world. The Constitution of the White Earth Nation declares a solemn association of these Native and Occidental traditions of human rights and liberty.

The Second Magna Carta, an anonymous document, was published in 1771, sixteen years before the adoption of the United States Constitution. Notably, the Second Magna Carta called for "forty-eight representatives from the American Colonies (including some for the Indian Nations) to be allotted seats at the Westminster Parliament.” The American Revolution concluded the inspired representation of Native Nations at the Parliament.

The United States Constitution was proposed and adopted by unanimous consent and signed by thirty-nine delegates at the Constitutional Convention in Philadelphia on September 17, 1787.

Seven Articles, including the last Article which is the "Ratification of the Conventions of nine States, shall be sufficient for the Establishment of this Constitution between the States so ratifying the Same.” Delaware was the first state to ratify on December 7, 1787. New Hampshire, the ninth state, confirmed the ratification on June 21, 1788. The Constitution was actually ratified by all thirteen states. The United States Constitution created a government on March 4, 1789. George Washington was elected the first president and took the oath of office on April 30, 1789.

"The fact that we purport to follow and be bound by the Constitution that was proposed in 1787, ratified in 1789, and formally amended just 27 times,” wrote Laurence Tribe in The Invisible Constitution, "is due, in large part, to the fact that it is a single and singular text, one writing, that memorializes the commitments defining us over the course of time in a ways that neither our physical territory nor the multiple ancestral origins of our nation can. Indeed, the physical writing itself-from the parchment 
signed in Philadelphia in 1787 and still carefully preserved at considerable expense in the National Archives to the numbered copies of the original that circulated physically throughout the several ratifying states-is almost instinctively treated with a devotion ordinarily accorded only to an object of national veneration, rather than any mere statute.”

The Constitution of the White Earth Nation was conceived by the stance of resistance, by the shared sentiments and associations of continental liberty, and by the epitome of cultural sovereignty and constitutional governance. The declaration and protection of human rights is a universal sentiment, and that promise has been ratified by the delegates in the Constitution of the White Earth Nation.

The first Ten Amendments to the United States Constitution, the Bill of Rights, provide the foundations of liberty, that no law respecting religion or prohibiting free expression thereof, the freedom of speech, assembly and petition of grievances, the right to keep and bear arms, no unreasonable searches or seizures, due process of law, speedy and public trial, no excessive bail, and powers not delegated to the United States by the Constitution are reserved to the States respectively, or to the people. The Bill of Rights was ratified in 1791. The Constitution has been amended only twenty-seven times in more than two hundred years.

"The American commitment to freedom of speech and press is the more remarkable because it emerged from legal and political origins that were highly repressive," observed Anthony Lewis in Freedom for the Thought That We Hate. "The colonists who crossed the Atlantic in the seventeenth century came from an England where it was extremely dangerous to utter a thought that differed from official truth. The state defined what was allowable in politics and, perhaps even more rigorously, in religion.”

The Fifth Amendment, ratified in 1868, at the same time the White Earth Reservation was established by federal treaty, provides that "Representatives shall be apportioned among the several States according to their respective numbers, counting whole numbers of persons in each State, excluding Indians not taxed.”

"Indians not taxed!”

Now, by the stories of resistance, courage, political and artistic irony, and a sense of survivance, our ancestors and families of the fur trade anticipated this extraordinary 
moment of continental liberty. The Anishinaabe delegates to the four conventions, taxed or not taxed, considered, compromised, and ratified the Constitution of the White Earth Nation.

The White Earth Constitution provides in each chapter a crucial composition of checks and balances, a distinct organization of the powers, measures, limitations, and constraints of three branches of government, the executive, legislative, and judicial. The composition of these powers of governance would embrace the necessary advice of the Community Councils, the Council of Elders, and the Youth Council.

"So the visible Constitution necessarily floats in a vast and deep-and, crucially invisible-ocean of ideas, propositions, recovered memories, and imagined experiences that the Constitution as a whole puts us in a position to glimpse," wrote Tribe in The Invisible Constitution.

The Constitution of the White Earth Nation contains two preambles, the first announces the sentiments of cultural sovereignty and continental liberty, and the second is a declaration of essential political sovereignty and inalienable rights. There are twenty chapters and one hundred eighteen specific articles on the branches of the government and the rights of the citizens.

I declared at the first Constitutional Convention that one day we would carry in our pockets a printed copy of the ratified Constitution of the White Earth Nation. The sworn delegates to the final Constitutional Convention have created by the ratification of this document, a great and memorable moment in the history of the White Earth Nation. The Constitution ensures a continuation of compassionate reciprocity, cultural sovereignty, survivance, and entitles the delegates and citizens to say with confidence, "I know my rights.” 


\section{THE CONSTITUTION OF THE WHITE EARTH NATION}

The Constitution of the White Earth Nation was duly ratified on April 4, 2009, at the Shooting Star Casino Hotel, Mahnomen, Minnesota.

Copyright $(C)$ by Gerald Vizenor

\section{Gerald Vizenor University of New Mexico}

\section{PREAMBLE}

The Anishinaabeg of the White Earth Nation are the successors of a great tradition of continental liberty, a native constitution of families, totemic associations. The Anishinaabeg create stories of natural reason, of courage, loyalty, humor, spiritual inspiration, survivance, reciprocal altruism, and native cultural sovereignty.

We the Anishinaabeg of the White Earth Nation in order to secure an inherent and essential sovereignty, to promote traditions of liberty, justice, and peace, and reserve common resources, and to ensure the inalienable rights of native governance for our posterity, do constitute, ordain and establish this Constitution of the White Earth Nation.

\section{CHAPTER 1: TERRITORY AND JURISDICTION}

The White Earth Nation shall have jurisdiction over citizens, residents, visitors, altruistic relations, and the whole of the land, including transfers, conferrals, and acquisitions of land in futurity, water, wild rice, public and private property, right of way, airspace, minerals, natural resources, parks, and any other environmental estates or territories designated by and located within the boundaries of the White Earth Reservation, as established and described in the Treaty of March 19, 1867, and over the reserved rights within the ceded waterways and territories of the Treaty of 1855. 


\section{CHAPTER 2: CITIZENS OF THE WHITE EARTH NATION}

\section{Article 1}

Citizens of the White Earth Nation shall be descendants of Anishinaabeg families and related by linear descent to enrolled members of the White Earth Reservation and Nation, according to genealogical documents, treaties and other agreements with the government of the United States.

\section{Article 2}

Services and entitlements provided by government agencies to citizens, otherwise designated members of the White Earth Nation, shall be defined according to treaties, trusts, and diplomatic agreements, state and federal laws, rules and regulations, and in policies and procedures established by the government of the White Earth Nation.

\section{Article 3}

The Anishinaabeg and their descendants shall have the right to appeal to the President and to the White Earth Court any decisions that deny citizenship in the White Earth Nation.

\section{Article 4}

No person or government has the privilege or power to diminish the sovereignty of the White Earth Nation.

\section{CHAPTER 3: RIGHTS AND DUTIES}

Article 1

The White Earth Nation shall make no laws that would establish a religion, or laws that would deny the free expression of religion, speech, or of the press and electronic communication.

\section{Article 2}

The White Earth Nation shall make no laws that deny the right of the people to peaceably gather or assemble for any reason, and shall make no laws that prohibit the right to petition the government for restitution, amendments, or redress of grievances, 
and no person shall be discriminated against for initiating or espousing an untimely or contrary petition about governance.

\section{Article 3}

The people shall not be denied the fundamental human rights of citizenship in the White Earth Nation.

\section{Article 4}

The people are equal under the law and no law, government policy, or agency practice shall discriminate in political, economic, social or cultural associations because of race, creed, sex, gender, disability, or social status.

\section{Article 5}

The freedom of thought and conscience, academic, artistic irony, and literary expression, shall not be denied, violated or controverted by the government.

\section{Article 6}

The secrecy of personal communication shall not be violated, and no censorship shall be practiced or maintained by the government.

\section{Article 7}

The right to own and transfer of private property is inviolable. The rights of property shall be protected, and private property expropriated for public use shall be according to due process of law and just compensation.

\section{Article 8}

No person shall be denied or deprived of life or liberty, except certain serious misdemeanors and felony convictions, and no criminal penalties shall be imposed without due process of law and judicial procedures.

\section{Article 9}

No person shall be apprehended by law enforcement officers without probable cause and due process of law or by warrant duly issued by a court. 
Article 10

The people shall have the right to possess firearms except for convicted felons in accordance with state and federal laws.

Article 11

The people shall be secure in their homes, personal papers and documents, against entries, electronic and material searches, without a specific, descriptive warrant for adequate cause issued by a court. Each search and seizure shall require a separate, specific warrant issued by a court, except in cases of probable threats or potential emergencies.

\section{Article 12}

No person shall be obligated to testify or provide evidence in a court against himself or herself, and any confessions obtained under compulsion, torture, or threats, or after arrest and excessive detention, may not be admissible as evidence in court. No person shall be convicted or punished for a crime when the only evidence against him or her is a confession, except in cases of crimes that can be proven by other evidence.

\section{Article 13}

No person shall be subject to trial twice for the same criminal indictment or offence.

\section{Article 14}

No person shall be denied the right to be duly informed of the nature and cause of a warrant, indictment, or criminal proceeding, and shall not be denied the right to be represented by legal counsel.

\section{Article 15}

The people shall have the right to confront and challenge witnesses in a criminal court, and the legal option of a speedy court hearing or public jury trial shall not be refused or contradicted.

Article 16

Citizens shall never be banished from the White Earth Nation. 
Article 17

The Constitution of the White Earth Nation is inspired by inherent and traditional sovereignty, and contains, embodies, and promotes the rights and provisions provided in the articles and amendments of the Indian Civil Rights Act of 1968, and the United States Constitution.

\section{CHAPTER 4: SOVEREIGN IMMUNITY}

The White Earth Nation declares sovereign territorial, political and cultural rights and powers as an independent government and immunity to civil law suits. The Legislative Council by certain formal policies and procedures shall have the right to waive the sovereign immunity of the government in the best interests of the White Earth Nation.

\section{CHAPTER 5: BOARD OF ELECTIONS}

Article 1

Citizens must be at least eighteen years old to vote in government referenda and elections.

Article 2

Election and voting procedures shall be established by an Election Code and managed by an independent Board of Elections appointed by the Legislative Council.

Article 3

The Board of Elections shall consist of five eligible citizen voters of the White Earth Nation. The Chief Judge of the Board of Elections shall administer and supervise election regulations and procedures according to provisions of the Election Code. The Chief Judge shall not vote as a member of the Board of Elections.

Article 4

Members of the Board of Elections shall ensure fair and impartial elections according to the Election Code and the Constitution of the White Earth Nation. 
Article 5

The Legislative Council shall resolve any challenges or allegations of impropriety of election laws or procedures.

Article 6

Citizens who become candidates for elected positions in the government shall not be members of the Board of Elections. The Legislative Council shall appoint the Chief Judge and replacements to the Board of Elections.

\section{CHAPTER 6: GOVERNANCE}

Article 1

The White Earth Nation shall be governed by a representative and elected Legislative Council.

Article 2

The Legislative Council shall consist of a President, or White Earth Chief, the Secretary Treasurer, and elected Representatives of acknowledged communities of the White Earth Nation.

Article 3

The respective communities shall be entitled to one elected Representative to serve on the Legislative Council.

\section{Article 4}

Communities shall be established or changed by petition, by population, historic or totemic associations, and ratified by a simple majority of eligible citizen voters in a general referendum.

\section{Article 5}

The President and the Secretary Treasurer shall be elected at large by eligible citizen voters of the White Earth Nation. 
Article 6

The President, Secretary Treasure, and Representatives of the Legislative Council shall be elected for no more than two four year terms, and staggered elections shall be ordered every two years.

\section{Article 7}

Two citizens of the White Earth Nation shall be elected at large to serve constituencies outside the White Earth Reservation in the State of Minnesota.

\section{Article 8}

The Legislative Council shall have the authority to propose changes in the count of elected Representatives based on changes in population or the number of acknowledged communities. Proposals to change the count of Representatives shall be subject to a majority vote of citizens in a referendum.

\section{Article 9}

Candidates for elected government offices shall be citizens who reside within the treaty boundaries according to the Treaty of March 19, 1867, of the White Earth Nation, except two citizen members of the Legislative Council who shall be elected at large in the State of Minnesota.

\section{Article 10}

Citizens who have been convicted of a felony may vote in elections and referenda but shall not be eligible to hold elected offices in the White Earth Nation.

Article 11

Candidates for elected government office shall be at least twenty-five years of age at the time of the election.

\section{Article 12}

The Legislative Council shall appoint a new President in the event of the death, resignation, incapacity, or removal of the duly elected President. The appointed President shall serve the remainder of the elected term of the office. 
Article 13

The Legislative Council has the power to initiate impeachment proceedings of elected representatives of the government for specific allegations of misconduct, criminal indictments, or felony convictions. To initiate impeachment procedures requires at least a two-thirds vote of the Legislative Council.

Article 14

There shall be two distinct procedures of impeachment. The first is admonition of misconduct but no other action or decree, and the second procedure is impeachment and removal from elected office.

\section{Article 15}

The White Earth Nation shall obligate candidates for elected offices not to disburse in campaign services, promotion and advertising more than three times the amount of the annual national family poverty guidelines, for one person in the Contiguous States, established and published in the Federal Register by the United States Department of Human Services.

Article 16

Candidates for elected office shall file a formal report no later than thirty days after the election with the Chief Judge of the Board of Elections. The report shall be an affirmation of total election contributions and disbursements of the candidate.

Article 17

The President and Legislative Council of the White Earth Nation shall maintain public records and documents for posterity. The President shall nominate an archive to secure the public records and documents.

\section{CHAPTER 7: COMMUNITY COUNCILS}

The Community Councils shall be initiated and established in geographically based communities by citizens of the White Earth Nation. The Community Councils shall provide communal information, guidance, and recommendations to both the Legislative Council and the President on matters of concern to the citizens. The Community 
Councils shall promote, advance and strengthen the philosophy of mino-bimaadiziwin, to live a good life, and in good health, through the creation and formation of associations, events and activities that demonstrate, teach and encourage respect, love, bravery, humility, wisdom, honesty and truth for citizens.

\section{CHAPTER 8: COUNCIL OF ELDERS}

The Council of Elders shall be nominated by citizens and designated by the Legislative Council. The Council of Elders shall provide ideas and thoughts on totemic associations, traditional knowledge, cultural and spiritual practices, native survivance, and considerations of resource management, and advice the Legislative Council. The Council of Elders shall consist of twenty citizens of the White Earth Nation who are at least fifty-five years of age at the time of appointment.

\section{CHAPTER 9: YOUTH COUNCIL}

The Youth Council shall be nominated by citizens and designated by the Legislative Council. The Youth Council shall provide information about matters that affect young people and advise the President and Legislative Council. The Youth Council shall consist of twenty citizens who are between the ages of twelve and eighteen, and who are residents of the White Earth Nation.

\section{CHAPTER 10: SEPARATION OF POWERS}

The White Earth Nation shall be divided into three separate branches of government. The Executive branch is the elected President, the Board of Elections, Council of Elders, Youth Council, and other executive designations. The Legislative branch includes the Representatives elected to the Legislative Council. The Judicial branch of government is the Judiciary and White Earth Courts. The three respective branches of government shall have no authority over any other branch, except for certain nominations and other provisions specified in the Constitution of the White Earth Nation. 


\section{CHAPTER 11: THE PRESIDENT}

\section{Article 1}

The President, or White Earth Chief, shall be the official national and international elected representative of the White Earth Nation.

\section{Article 2}

The President shall have the authority to secure and accept grants, negotiate agreements with associations, foundations, organizations, institutions, corporations, municipal, state, federal, and local governments, and other states and nations in the world with the ratification of the Legislative Council.

\section{Article 3}

The President shall be responsible for the administration and management of the government, and shall implement and execute the laws, ordinances, resolutions, and other enactments of the Legislative Council.

\section{Article 4}

The President shall approve by signature the laws, ordinances, measures, resolutions and appropriations of the Legislative Council.

\section{Article 5}

The President shall have the power to veto proposed laws, ordinances, measures, and resolutions initiated by the Legislative Council.

\section{Article 6}

The President shall return within five days vetoed or rejected proposed laws, ordinances and measures with a required statement of objection.

\section{Article 7}

The Legislative Council may overcome any veto of proposed laws, ordinances and resolutions by a two-thirds vote of the elected Representatives.

\section{Article 8}

The President shall have the authority to appoint executive branch administrators and other officials to serve the White Earth Nation. 
Article 9

The President shall have the power to schedule and preside over sessions of the Legislative Council.

Article 10

The President shall not vote except in the case of a tie vote of the Legislative Council.

Article 11

The President shall deliver an annual address dedicated to the State of the White Earth Nation.

Article 12

The President shall be bonded as an elected official.

Article 13

The President may serve no more than two four year elected terms.

Article 14

The President shall promote, protect, and defend cultural and political sovereignty and the Constitution of the White Earth Nation.

Article 15

The President shall have the authority to nominate honorary ambassadors, consuls, citizens, and to initiate and establish embassies of the White Earth Nation to serve the national and international concerns of native survivance and moral equity.

\section{CHAPTER 12: THE LEGISLATIVE COUNCIL}

Article 1

Representatives of the Legislative Council shall propose and enact laws, codes, ordinances, resolutions, and statutes of the White Earth Nation.

Article 2

The Legislative Council shall have the authority to raise general revenue, levy and collect taxes for government services and operations, establish license and service fees, 
and initiate other specific levies and taxes for the welfare of the citizens of the White Earth Nation.

\section{Article 3}

The Legislative Council shall have the authority to borrow money, issue public bonds, appropriate funds for the operation of the government, and to initiate other monetary policies in the interests of the White Earth Nation.

\section{Article 4}

The Legislative Council shall promote and protect the health, public welfare, safety, education, and the cultural and political sovereignty of the citizens of the White Earth Nation.

\section{Article 5}

The Legislative Council shall establish subordinate and secondary boards, appoint delegates, and reserves the right to review the initiatives and actions of the delegates and boards.

\section{Article 6}

The Legislative Council shall be responsible for the proper management of government programs, land, waterways, resources, commerce, public housing, transportation, casino operations, business enterprises, and other assets of the White Earth Nation.

\section{Article 7}

The Legislative Council shall have the authority to control the distribution and sale of alcoholic beverages within the treaty boundaries of the White Earth Nation.

\section{Article 8}

The Legislative Council shall not establish, support, or embody any covert political, military, or intelligence operations, without due process of law and legal warrants, against peaceable citizens of the White Earth Nation.

\section{Article 9}

The Legislative Council shall have residual powers, and the powers of governance provided, specified and entrusted in the Constitution shall not be construed as the 
limitation of legislative power or authority. The powers of the government not specifically expressed or entrusted to the Legislative Council shall be reserved to the citizens of the White Earth Nation.

\section{CHAPTER 13: THE SECRETARY TREASURER}

Article 1

The Secretary Treasurer shall be bonded and responsible for monetary and financial matters, resources, documents and records of the Legislative Council. Government records shall be available for public inspection and review.

Article 2

The Secretary Treasurer shall schedule an annual audit of funds, monetary transactions and records, deposits and expenditures by a duly certified independent auditor.

Article 3

The Secretary Treasurer shall carry through official duties and responsibilities of the President and the Representatives of the Legislative Council.

Article 4

The Secretary Treasurer shall be a voting member of the Legislative Council.

Article 5

The Secretary Treasure shall provide and publish an annual fiscal report and accounting of the White Earth Nation.

\section{CHAPTER 14: THE JUDICIARY}

Article 1

The Judiciary shall consist of the White Earth Court, Court of Appeals, and other courts established by the Legislative Council. 
Article 2

The White Earth Court shall have the power of judicial review and jurisdiction over any legal matters, disputes, civil procedures and criminal laws, ordinances, regulations, codes and customs of family relations, protection, and dissolution, adoption, domestic violence, juvenile justice, and probate, housing and property, conservation, taxation, governance, the corporate code, election disputes, and constitutional issues of the White Earth Nation.

Article 3

The Court of Appeals shall have original and appellate jurisdiction. The Court of Appeals shall hear case appeals and issues initiated by the Legislative Council. Decisions of the Court of Appeals are conclusive.

\section{CHAPTER 15: POWERS OF THE WHITE EARTH COURTS}

\section{Article 1}

The Courts shall have the authority to interpret and construe the laws, ordinances, and regulations of the Legislative Council and the Constitution of the White Earth Nation.

\section{Article 2}

The Courts shall issue legal decisions, injunctions, reviews, writs of mandamus, extradition, certiorari, writs of habeas corpus, and other legal orders, instruments and documents.

\section{Article 3}

The Courts shall establish procedures, rules, legal forms, and review by formal requests of citizens the specific and comprehensive constitutional validity of laws, ordinances and codes initiated and passed by the Legislative Council.

\section{Article 4}

The Courts shall ensure and practice restorative justice in civil actions, minor criminal offences, juvenile and family matters, whenever appropriate to resolve complaints and disputes of the White Earth Nation. 
Article 5

The Courts shall establish and publish a code of judicial ethics.

\section{CHAPTER 16: THE WHITE EARTH JUDGES}

Article 1

The White Earth Court shall consist of a Chief Judge and Associate Judges. The Chief Judge shall be appointed and removed by the Legislative Council.

Article 2

The Chief Judge shall appoint the necessary number of Associate Judges for five-year terms with the consent of the Legislative Council.

Article 3

The Court of Appeals shall consist of three judges and shall be appointed by the Legislative Council in consultation with the Chief Judge.

Article 4

The Chief Judge shall not be a member of the Court of Appeals.

Article 5

Judges of the Court of Appeals shall serve for five-years, and may otherwise practice law or be associated with a law firm.

Article 6

The judges of the courts shall be at least twenty-five years of age, of proven moral character, and who have not been convicted of a felony.

Article 7

The judges shall be graduates of a law school accredited by the American Bar Association.

Article 8

The judges shall be admitted to the bar to practice law in native communities, state, or federal courts. 
Article 9

The judges shall be experienced lawyers, magistrates, or judges.

Article 10

The judges shall have knowledge of Anishinaabe culture, traditions, and general history.

Article 11

The judges shall recuse themselves, an assertion of judicial disqualification, as unsuitable to perform legal duties where there are possible conflicts of interest, or the appearance of personal interests, or potential challenges of partiality.

Article 12

The judges shall be impeached by the Legislative Council and removed from judicial practice for abuses of impartiality, bribery, political impropriety, or felony conviction.

\section{CHAPTER 17: LEGISLATIVE COUNCIL MEETINGS}

Article 1

The Legislative Council shall meet at least once each month to conduct government business. The time and place of each session shall be posted in advance.

Article 2

Citizens of the White Earth Nation have the right to attend sessions of the Legislative Council.

Article 3

The President has the authority to schedule special and emergency sessions of the Legislative Council.

Article 4

The Legislative Council by a majority vote and written request shall have the authority to schedule a special session. 


\section{Article 5}

The President shall be obligated to schedule a special session of the Legislative Council by an official petition of thirty percent of eligible citizen voters of the White Earth Nation.

Article 6

The President may schedule an emergency session of the Legislative Council without written notice to consider urgent matters, services, protection of the health, welfare and safety of the citizens and communities of the White Earth Nation.

\section{Article 7}

The Legislative Council shall conduct no other business than the specific stated purpose of an emergency session.

\section{Article 8}

The Legislative Council shall have the authority to meet in closed executive sessions with the President to discuss matters of litigation, proposed and discreet negotiations, and other concerns of confidentiality.

\section{Article 9}

The Legislative Council shall not decide actions on matters of litigation or confidentiality in closed executive sessions except when the outcome of the session has been fully reported in subsequent public sessions of the Legislative Council. The results of executive sessions shall be decided by vote at a public meeting.

Article 10

Legislative Council motions, votes, resolutions and decisions shall be noted and preserved in the official minutes of the sessions.

Article 11

Legislative Council actions, decisions, and enactments of record shall be available for inspection by citizens during normal business hours of the government. 
Article 12

The Legislative Council shall date and number each and every resolution, ordinance, law and statute, and cite the appropriate authority of the Constitution of the White Earth Nation.

Article 13

The Legislative Council shall prepare a certificate for each resolution, ordinance, and statute that confirms the presence of a quorum and indicates the number of members voting for or against each enactment.

Article 14

The Legislative Council shall constitute a quorum by a simple majority of fifty-one percent of the elected members at a duly schedule session.

\section{CHAPTER 18: ETHICS AND IMPEACHMENT}

Article 1

Elected members of the government may be impeached or removed from office by a recorded two-thirds vote of the entire Legislative Council.

Article 2

The Legislative Council may impeach or remove from office an elected member of government for a felony conviction in a court of competent jurisdiction.

Article 3

The Legislative Council may impeach or remove from office an elected member of the government for two misdemeanor convictions, including driving while intoxicated, but not including ordinary traffic violations.

Article 4

Elected officials of the government may not be suspended or removed from office without due process of law. 
Article 5

The Legislative Council may impeach for cause an elected member of the government. The impeachment may be a form of admonition, a warning or legal statement of charges, or the impeachment may be based on an indictment or conviction for a felony, and the forcible removal of an official of the government.

Article 6

The White Earth Nation shall provide for a recall election of an elected official of the government. Citizens have the right to initiate a petition to recall an elected official. The petition shall secure at least two-thirds of the eligible voters for a recall election. The petition may be political and may include allegations, grievances, complaints and assertions of misconduct, nonfeasance, or mismanagement by an elected official of the government.

\section{CHAPTER 19: PETITIONS AND REFERENDA}

Article 1

The Legislative Council may initiate a referendum by a vote of two-thirds of the elected Representatives.

\section{Article 2}

Citizens of the White Earth Nation may initiate a referendum by evidence of a vote of thirty percent of the eligible citizen voters.

\section{Article 3}

The Legislative Council and eligible citizens may present proposed laws, ordinances, and initiatives to a referendum vote of the electorate, according to certified evidence of the constitutional process.

\section{Article 4}

The referendum vote shall be held within one hundred and eighty days from the official receipt of the petition, unless the scheduled date of the referendum is within six months of a general election, in that event the referendum would be presented to the eligible voters in the general election. 
Article 5

Scheduled referenda shall be conducted according to the rules and regulations of the Board of Elections and the Election Code.

\section{CHAPTER 20: AMENDMENTS TO THE CONSTITUTION}

The Constitution of the White Earth Nation may be amended by two-thirds of the recorded eligible votes in a duly called election or referendum to amend the Constitution. Eligible voters must be formally informed by written and published notices of the proposed amendment to the Constitution of the White Earth Nation.

\section{RATIFICATION OF THE CONSTITUTION}

The sworn delegates to the White Earth Constitutional Convention hereby duly ratify for a citizen referendum the Constitution of the White Earth Nation.

The Constitution of the White Earth Nation was duly ratified on April 4, 2009, at the Shooting Star Casino Hotel, Mahnomen, Minnesota.

The ratification was by secret ballots of twenty-four delegates present. Sixteen delegates voted for ratification, and eight delegates votes against ratification.

Gerald Vizenor, Distinguished Professor of American Studies at the University of New Mexico, was a delegate to the Constitutional Convention and the Principal Writer of the proposed Constitution of the White Earth Nation.

The Constitution Proposal Team included Erma Vizenor, President of the White Earth Nation, Jill May Doerfler, Assistant Professor, Department of Indian Studies, University of Minnesota, Duluth, Jo Anne E. Stately, Vice President of Development for the Indian Land Tenure Foundation, and Anita Fineday, Chief Tribal Court Judge, White Earth Nation.

David E. Wilkins, Professor of American Indian Studies, University of Minnesota, was a Special Consultant to the Constitutional Convention and the Proposal Team. 
Anton Treuer, Professor, American Indian Resource Center, Languages and Ethnic

Studies, Bemidji State University, was the translator of the Preamble to the Constitution.

Received May 2009

Cite this article as:

Vizenor, G. 2009. "Constitution of the White Earth Nation”. Language Value, 1 (1), 51-80. Servei de Publicacions de la Universitat Jaume I: Castelló, Spain. http://www.e-revistes.uji.es/languagevalue.

ISSN 1989-7103

Articles are copyrighted by their respective authors 